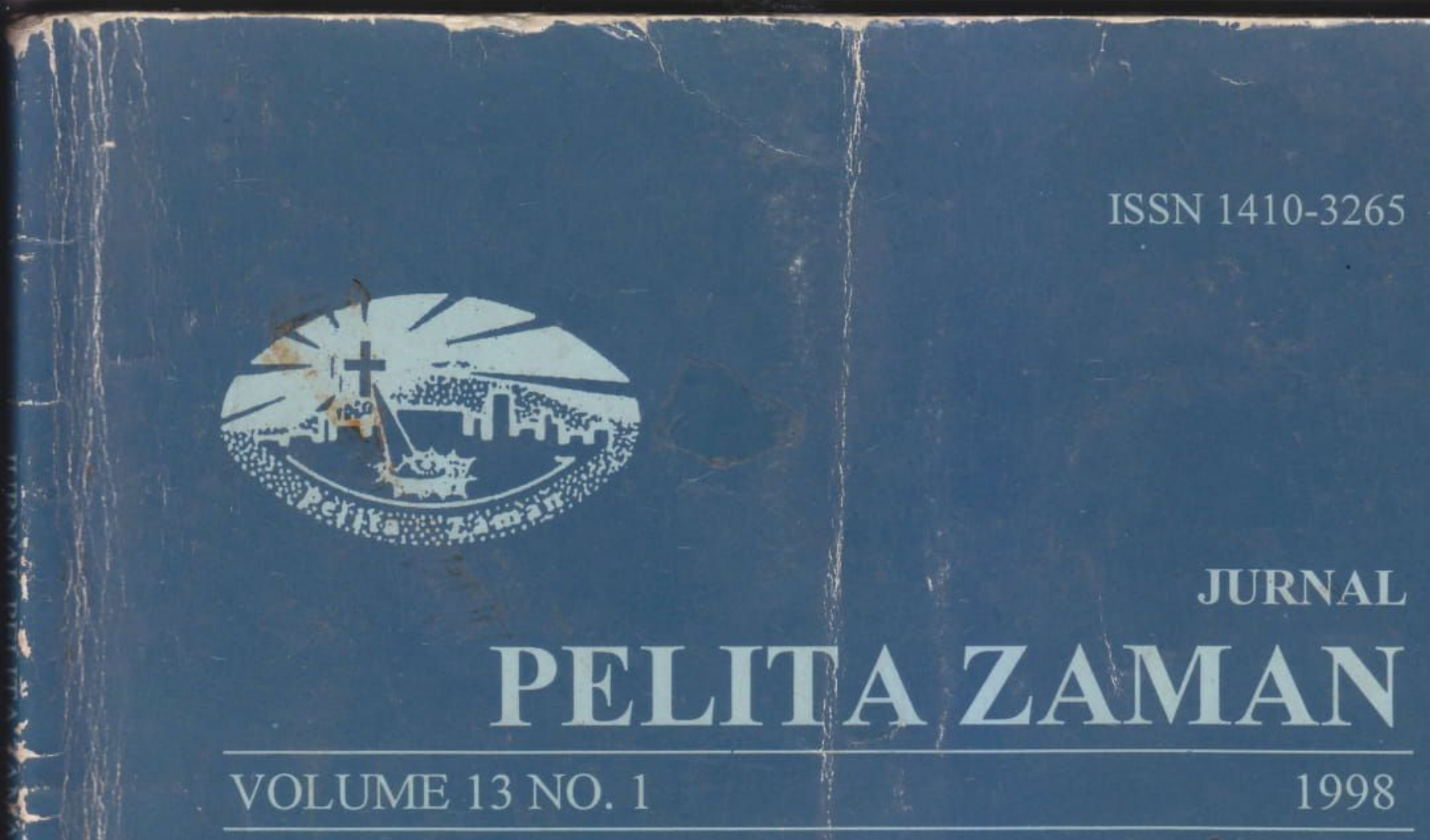

Hak Asasi Manusia dan Kasih Sayang Yesus Kristus 1 Franz Magnis-Suseno, SJ

Etika Lingkungan Hidup Dari Perspektif Teologi Kristen

Robert P. Borrong

Hubungan Agama - Negara Dalam Perspektif Negara Pancasila (Sebuah Telaah Etis)

Eka Darmaputera

Keprihatinan Allah Terhadap Wong Cilik

(Perspektif Perjanjian Lama)

Amos Sukamto

Kapitalisme: Dari Masa Ke Masa

Arya W. Darmaputera

Feminisme: Sumbangsih Dan Kritik

Insriatmi Paimoen

Memperkenalkan Injil Tomàs

66

Rudiyanto

Tinjauan Buku

Yonky Karman 


\section{KEPRIHATINAN ALLAH TERHADAP WONG CILIK (Perspektif Perjanjian Lama)}

\section{Amos Sukamto}

Di dalam sejarah perjuangan dan pergumulan bangsa Indonesia, wong cilik selalu mendapat tempat perhatian yang menarik. Munculnya banyak organisasi LSM akhir-akhir ini sering dikaitkan dengan keberadaan dan kekurang-beruntungan kelompok masyarakat yang sering disebut wong cilik. Organisasi-organisasi politik pun tak mau kalah untuk menyuarakan dirinya berpihak pada wong cilik, dengan tujuan supaya organisasi parpol tersebut memperoleh suara yang banyak. Kenapa? Karena pada kenyataannya wong cilik merupakan kelompok masyarakat terbesar yang berdiam di bumi Indonesia.

Wong cilik selalu menjadi isu yang menarik, dan tulisan ini ditulis untuk memahami seberapa jauh Allah, Sang Pencipta dan Penebus atas para wong cilik, itu sendiri berprihatin terhadap keadaan sosial ciptaanNya. Keprihatinan-keprihatinan Allah itu yang akan menjadi dasar teologis buat kita, terutama orang-orang percaya untuk ikut terlibat, berpartisipasi dalam pelayanan kita kepada kelompok masyarakat yang kurang beruntung yaitu wong cilik.

Dalam penjabarannya, tulisan ini akan dibagi menjadi tiga bagian: pada bagian pertama akan dibahas keadaan sosial wong cilik dalam konteks pemahaman Indonesia; bagian kedua, keadaan sosial wong cilik dari perspektif Perjanjian Lama; dan pada bagian ketiga akan dibahas wujud keprihatinan Allah terhadap wong cilik.

\section{A. Wong Cilik dan Status Sosialnya dalam Konteks Indonesia.}

Wong cilik ${ }^{1}$ adalah sebuah istilah yang digunakan untuk membedakan status sosial dalam masyarakat Jawa. Dalam penggunaannya wong cilik selalu dikontraskan dengan istilah priyayi. Masyarakat yang dikelompokkan ke dalam golongan wong cilik adalah sebagian besar massa petani, petani gurem, para pekerja kasar, para pedagang kecil, buruh kecil, di mana kelompok ini merupakan masyarakat kebanyakan dan menjadi lapisan masyarakat bawah. Magnis-Suseno membedakan arti wong cilik dan orang miskin sebagai berikut: "Antara orang kecil dan orang miskin tidak sama. Orang miskin termasuk orang kecil, sedangkan orang kecil hidupnya sederhana, tapi belum tentu miskin." 
Memang betul bahwa wong cilik belum tentu miskin, tetapi mereka adalah kaurn yang powerless artinya mereka tidak mempunyai kuasa atau kaum yang lemah dan tak berdaya sehinga mudah untuk dieksploitasi dan dimiskinkan. Jadi walaupun mereka tidak miskin tetapi mereka sangat mudah untuk dimiskinkan. Secara mudah saya gambarkan sebagai berikut: walaupun wong cilik punya tanah yang cukup tetapi karena kondisi kepowerless-annya maka dengan mudah tanah mereka digusur dengan paksa oleh pihak yang lebih berkuasa. ${ }^{3}$ Sehinga saya sangat setuju bila wong cilik didefinisikan sebagai berikut:

... mereka ini staiah "orang yang tak berdaya karena mengalami aneka macain pemiskinan ... yang membuat semakin banyak orang hidup semakin tidak manusiawi dan tidak menggan.barkan bahwa dia adalah citra Aliah yang bermartabat sebagai manusia". (no 6) "Pada umumnya mereka hidup di bawah taraf kewajaran manusiawi". (no 7)

\section{B. Wong Cilik, Perspektif dari Perjanjian Lama}

Setelah kita mendefinisikan wong cilik dalam konteks Indonesia maka sekarang kita akan meneliti bagaimana Alkitab khususnya Perjanjian Lama berbicara tentang status sosial wong cilik.

\section{Perkembangan Sosial Ekonomi Bangsa Israel}

Pada periode paling awal bangsa Israel hidup sebagai bangsa nomaden. Struktur sosialnya masih bersifat kesukuan, di mana suatu kelompok masyarakat percaya bahwa mereka berasal dari satu nenek moyang yang sama. Akibat dari sistem sosial yang demikian, maka kondisi hidup yang merata masih bisa dengan mudah dijaga. Apalagi pada waktu itu ada bentuk organisasi yang bernama goel. Organisasi ini berfungsi sebagai penebus, penolong dan pelindung bagi saudaranya yang lemah. Jika salah satu di antaranya menjadi miskin dan menjual dirinya sebagi budak, maka goel iniliah yang wajib menebusnya (Im 25:47-49). ${ }^{5}$

Tetapi keadaan seperti ini berubah setelah masa monarki yaitu sebuah masa di mana sistem pemerintahannya diatur oleh seorang raja. Ini terjadi kira-kira pada abad ke-11 SM. Timbulnya pemerintahan yang berbentuk kerajaan ini menciptakan kelas-kelas elit baru, dan mencapai titik yang menyedihkan pada abad ke-8 SM. Di mana tampuk kepemimpinan pemerintahan pada waktu itu dipegang oleh Raja Uzia dan Raja Yerobeam II. Pada masa ini terjadi ledakan kemajuan di bidang ekonomi secara cepat. Tetapi sayangnya ledakan ini hanya dinikmati oleh beberapa orang yang tentunya orang-orang yang dekat pada para penguasa pada waktu itu. Sehingga kesenjangan sosial tidak dapat dihindarkan untuk terbentuk, 
yang berkuasa semakin mendapat angin untuk berkuasa dan yang lemah semakin mendapat angin untuk mendapat tekanan.

Timbullah kesewenang-wenangan dari pihak yang merasa dirinya kuat dan sebagai penguasa. Kesewenang-wenangan ini tampak dalam bentukbentuk tindakan penindasan kepada kaum 'ani, 'ebhyon dan dal yaitu kaum yang lemah atau lebih tepat disebut sebagai wong cilik. Para penguasa menjual wong cilik karena uang dan sepasang kasut artinya mereka dijual dengan harga yang sangat rendah sekali (Am 2:6). Para penguasa menginjak-injak kepala orang lemah ke dalam debu dan membelokkan jalan orang sengsara (Am 2:7); memberi suap kepada para nabi untuk berhenti menyampaikan kebenaran, dan menyuap para hakim untuk membelokkan keadilan (Am 2:12; 5:12); dan memeras orang miskin (Am 4:1).

\section{Wong Cilik dan Status Sosialnya}

Perbendaharaan kata dalam Perjanjian Lama yang artinya senada

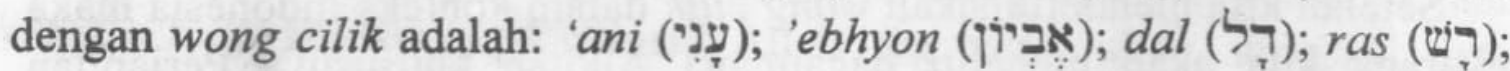

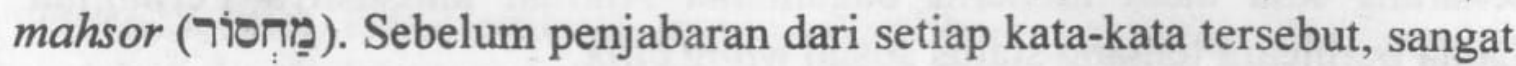
perlu untuk menyebutkan bahwa di dalam Perjanjian Lama ada tiga kelompok yang biasanya digolongkan sebagai wong cilik. Kelompok itu adalah para janda, anak-anak yatim, dan orang pengembara (Im 19:10; 23:22; Ayub 29:12-13; Zak 7:9-10). Meskipun mereka tidaklah selalu miskin, tetapi ada kecenderungan bahwa mereka mudah untuk menjadi miskin. Di dalam suatu struktur masyarakat yang didominasi oleh kaum laki-laki maka seorang janda akan tidak mampu bersaing dengan lawanlawannya, apalagi seorang yatim. Mereka adalah kaum lemah yang mudah mendapat penindasan dari orang lain.

'ani (עָנִיר)

Kata ani merupakan kata umum dalam bahasa Ibrani yang digunakan untuk menunjuk ke istilah miskin. Meskipun dalam penggunaannya sering disejajarkan dengan 'ebhyon dan dal, tetapi artinya berbeda dari keduanya; 'ani lebih menunjuk kepada ketidakberdayaan. ${ }^{6}$ Kata ini digunakan 7 kali dalam kitab Pentateukh (Kel 22:25; Im 19:10; 23:22; Ul $15: 11 ; 24: 12,14,15)$ dan mempunyai hubungan yang jelas dengan keadaan miskin secara ekonomi: "Jika engkau meminjamkan uang kepada salah seorang dari umat-Ku, orang yang 'ani di antaramu, ..." (Kel 22:25); "Juga sisa-sisa buah anggurmu janganlah kaupetik untuk kedua kalinya dan buah yang berjatuhan di kebun anggurmu janganlah kaupungut, tetapi 
semuanya itu harus kautinggalkan bagi orang 'ani ..." (Im 19:10; bdk. 23:22); "Sebab orang-orang 'ani tidak hentinya akan ada di dalam negeri itu; itulah sebabnya aku memberi perintah kepadamu, demikian: Haruslah engkau membuka tangan lebar-lebar bagi saudaramu yang 'ani' dan yang 'ebhyon di negerimu" (Ul 15:11).

Kaum 'ani dalam Pentateukh adalah kaum yang kekurangan kebutuhan hidup, dan secara sosial mereka tidak berdaya dan mudah menjadi obyek penindasan.

Di dalam kitab nabi-nabi kaum 'ani pun lebih banyak mendapat sorotan. Kata ini muncul 25 kali yaitu: Yes $3: 14,15 ; 10: 2,30 ; 14: 30 ; 26: 6$; $32: 7 ; 41: 17 ; 49: 13 ; 51: 21 ; 54: 11 ; 58: 7 ; 66: 2$; Yer 22:16; Yeh 16:49; 18:12,16; 22:29; Am 8:4; Hab 3:14; Zef 3:12; Za 7:10; 9:9; 11:7,11).

Konsep 'ani dalam literatur nabi-nabi lebih berkembang artinya dibandingkan dengan konsep 'ani dalam Pentateukh. Dalam literatur nabinabi konsep ini tidak hanya menunjuk kepada kekurangan kebutuhan hidup, tetapi lebih dari itu, yakni menunjuk kepada kaum yang ditindas, diperkosa hak asasinya dan dimiskinkan. ${ }^{7}$ Yesaya 3:15 menggambarkan dengan jelas: "Mengapa kamu menyiksa umat-Ku dan menganiaya orangorang yang 'ani?" "Dengarlah ini, kamu yang menginjak-injak orang "ani."

Di dalam sejarah penyelidikan Perjanjian Lama, identitas kaum miskin di dalam kitab Mazmur masih terus menjadi subyek diskusi yang menarik. Misalnya, Rahlfs menyatakan bahwa kaum miskin adalah sebuah kelompok yang khusus di antara umat Allah, dalam Perjanjian Lama, yang menyatakan komitmen dirinya menjadi pengikut Yahweh. ${ }^{8}$ Coggins menyatakan bahwa kaum miskin dalam kitab Mazmur tidak menunjuk kepada miskin dalam arti ekonomi: "... there is nothing in the Psalm which would suggest material poverty." Gillingham mengusulkan pemahaman baru dalam memahami kaum miskin di kitab Mazmur, dia percaya bahwa:

Four main words in the Psalter which describe the poor cannot be classified neatly in terms of economic deprivation (Blessed are you poor ... as in Lk. 6:20), or even in terms of a particular religious group (Blessed are the poor in spirit ... as in Mt. 5:3).

Lebih lanjut dia menyatakan:

Although many references are highly ambiguous, it will be seen that a complex variety of life-settings is sugested, both individual and communal, and different aspects of suffering are implied, both physical and spiritual.

Kata 'ani muncul 31 kali di dalam kitab Mazmur. Kata ini menunjuk kepada (1) bangsa yang ditindas secara fisik oleh kuasa bangsa lainnya 
(Mzm 9-10), "Sebab Dia, yang membalas penumpahan darah, ingat kepada orang yang 'ani ... (9:13); "Bangkitlah TUHAN! Ya Allah, ulurkanlah tangan-Mu, janganlah lupakan orang-orang yang 'ani (10:12). (2) Orang yang diperlakukan secara tidak adil, "Berilah keadilan kepada orang yang lemah dan kepada anak yatim, belalah hak orang sengsara dan orang yang kekurangan! Luputkanlah orang yang lemah dan yang 'ani, lepaskanlah mereka dari tangan orang fasik!" (82:3-4). (3) Kaum yang kekurangan kebutuhan pangan, "Perbekalannya akan memberkati dengan limpahnya, orang-orangnya yang 'ani akan kukenyangkan dengan roti (132:15). (4) Orang-orang yang mencari pertolongan kepada Allah dalam mengusahakan keadilan $(10: 1-2 ; 18: 28 ; 25: 16 ; 34: 7 ; 35: 10 ; 102: 1)$.

Dalam Kitab Ayub kata ani muncul 7 kali. Kitab Ayub menggambarkan penderitaan kaum 'ani dengan lebih jelas; mereka adalah kaum yang ditindas (24:4), kaum yang anaknya digadaikan karena kondisi kemiskinannya (24:5), dan kaum korban dari pembunuhan yang semenamena oleh penguasa $(24: 14)$.

\section{'ebhyon (אֶבְיוֹן)}

Kata 'ebhyon berasal dari akar kata אבה. Secara umum kata אבה berarti "to lack, to be in need." 12 Kata ini muncul sebanyak 9 kali dalam Kitab Pentateukh (Kel 23:6,11; Ul 15:4, 7 (2x), 9, 11 (2x); 24:14). Sebanyak dua kali digunakan secara bersama-sama dengan kata עָנִ (Ul $15: 11 ; 24: 14)$. Kata ini menunjuk kepada (1) kaum lemah yang mudah diperkosa hak hidupnya ( $\operatorname{Kel} 23: 6$ ); (2) kaum yang kehilangan tanah warisannya (23:11); (3) kaum yang menerima santunan dari orang lain (Ul $15: 7-8)$; dan (4) kaum yang tertimpa hutang dan tidak bisa mengembalikannya (Ul 15:9-11).

Kata 'ebhyon di dalam kitab Nabi-nabi muncul sebanyak 17 kali. Kata ini digunakan untuk menggambarkan (1) kaum yang terinjak-injak harkat kemanusiannya (Am 8:4); (2) kaum yang teraniaya oleh para penguasa dalam masyarakat dan struktur sosial yang buruk (Yer 2:34; 20:13; Yeh 18:12; Am 4:1); (3) kaum yang tidak mendapat perlakuan secara adil di dalam lembaga pengadilan, "... dan tidak membela hak orang 'ebhyon." (Yer 5:28); "Sebab Aku tahu perbuatanmu yang jahat banyak dan dosamu berjumlah besar, hai kamu yang menjadikan orang benar terjepit, yang menerima uang suap dan yang mengesampingkan orang 'ebhyon di pintu gerbang" (Am 5:12, bdk. Yes 32:7). Botterweck mengatakan bahwa di dalam Kitab Yeremia 'ebhyon berarti secara sosial miskin, yang menurut Yer 5:28 harus menderita di bawah kebahagiaan dan ketamakan orangorang kaya karena mereka tidak mendapat keadilan secara adil. ${ }^{13}$ 
Kaum yang jatuh dalam perbudakan karena sebagai ganti untuk membayar hutang mereka, "... Oleh karena mereka menjual orang benar karena uang dan orang 'ebhyon karena sepasang kasut' (Am 2:6b, bdk. 8:6).

Di dalam kitab Mazmur kata 'ebhyon muncul 23 kali. Kata ini sering disejajarkan dengan kata 'ani. 'ebhyon dalam kitab Mazmur menggambarkan keadaan (1) kaum lemah yang ditindas oleh orang-orang yang jahat $(72: 12-14 ; 107: 41 ; 112: 9) ;(2)$ kaum yang merupakan kebalikan dari kaum kaya (49:3); dan (3) kaum yang dimiskinkan (pemiskinan materi) (35:10). Gillingham menambahkan bahwa: "di dalam Mazmur yang bersifat ratapan pribadi ada aspek lain yang dikenalkan yaitu pemazmur percaya bahwa Allah akan membela mereka, bukan hanya karena mereka miskin tetapi karena jalan yang mereka tempuh adalah percaya kepada Allah dengan kerendahan hati."

Di dalam Kitab Amsal kata 'ebhyon muncul 4 kali. Dalam kitab Amsal pasal 30-31, kata 'ebhyon diparalelkan dengan kata 'ani. dengan menunjuk kepada (1) kaum yang dieksploitasi oleh para penguasa (30:14), (2) kaum yang menjadi obyek ketidakadilan (31:9), dan (3) kaum yang membutuhkan pertolongan dari orang lain (31:20).

dal (דרל)

Kata dal merupakan kata yang berasal dari Ugaritic yang berarti "poor, needy" ${ }^{15}$ Kata dal muncul sebanyak 5 kali dalam Pentateukh (Kej 41:19; Kel 23:3; 30:15; Im 14:21; 19:15). Kata pertama yang muncul (Kej 41:19) digunakan untuk menggambarkan kondisi lembu yang kurus di dalam mimpinya Firaun. Karena kata ini berhubungan dengan kondisi lembu yang kurus dan.buruk bahkan kondisi semacam itu tidak pernah dijumpai sebelumnya di antara lembu-lembu di seluruh tanah Mesir, maka sangatlah wajar bila di dalam perkembangan berikutnya dal digunakan untuk melukiskan keadaan wong cilik yang miskin, tertindas dan terampas hak-hak kewajarannya sebagai seorang manusia. ${ }^{16}$

Di dalam kitab Keluaran makna kata dal berbeda dengan kata 'ani dan 'ebhyon. Biasanya seperti yang telah kita lihat di atas, kaum 'ani dan 'ebhyon selalu ditempatkan pada posisi yang mendapat perlakuan yang tidak adil di lembaga peradilan, tetapi di dalam Kel 23:3 dikatakan: "Juga janganlah memihak kepada orang dal dalam perkaranya." Ada dimensi makna yang berbeda antara kaum yang digolongkan sebagai kelompok dal dengan kelompok 'ani dan 'ebhyon. Lebih jelas dapat dilihat dalam Kel 30:15: "Orang kaya janganlah mempersembahkan lebih dan orang miskin [dal] janganlah mempersembahkan kurang dari setengah syikal ...", padahal di dalam Imamat 14:21 kaum dal diijinkan membawa 
persembahan yang kurang dari standar yang telah ditetapkan. Sehingga bisa disimpulkan bahwa kaum dal dalam kitab Keluaran adalah kaum yang tidak sama dengan kaum 'ani dan 'ebhyon, yang artinya kaum yang tidak mempunyai harta sama sekali yang hidupnya hanya tergantung dari belas kasihan orang lain; sedangkan kaum dal adalah kaum yang masih mampu membiayai kehidupannya sehari-hari, atau bisa lebih tepat mereka adalah petani-petani kecil. Mereka adalah kelompok sosial kelas yang powerless sehingga mudah untuk ditindas oleh para penguasa. Ini bisa kita lihat perubahan pemakaian kata dal di dalam kitab Nabi-nabi.

Di dalam kitab nabi-nabi kata dal muncul sebanyak 12 kali. Kata ini sudah berganti maknanya (sesuai dengan perubahan struktur sosial yang ada). Kata ini dipakai untuk menggambarkan (1) kaum yang menderita karena eksploitasi dan penindasan dari kaum kuat, "karena mereka menginjak-injak kepala orang dal ke dalam debu ..." (Am 2:7; bdk. 4:1); (2) kaum yang dipaksa untuk membayar pajak kepada para penguasa tanah (Am 5:11); dan (3) kaum yang dilecehkan dalam hukum-hukum hutang perbudakan (Am 8:6); (4) kaum yang dilecehkan dalam lembaga pengadilan, “... untuk menghalang-halangi orang-orang lemah [dal] mendapat keadilan ... (Yes 10:2). Tidak dipungkiri bahwa kata dal di beberapa tempat di kitab Yesaya dan Yeremia digunakan dalam arti simbolis, yaitu dalam Yer 5:4 dan Yes 14:30.

Kata dal dalam Mazmur muncul 4 kali. Kata ini digunakan untuk mengambarkan keadaan komunitas yang rendah secara status sosialnya sehingga mudah untuk ditindas (82:3-4), maka Tuhan menjanjikan berkat buat orang yang memperhatikan kaum dal.

Kafang yang memahami kemiskinan di kitab Mazmur lebih menitikberatkan pada dimensi miskin secara rohani, berpendapat bahwa kata dal dalạm Mazmur menggambarkan orang yang secara sosial, fisik dan ekonomi adalah lemah dan tak berpengharapan. ${ }^{17}$

Di dalam Amsal kata dal menunjuk kepada kaum yang tidak punya teman, kaum yang membutuhkan kebaikan dari orang lain (Amsal 19:17), dan yang membutuhkan pembagian rezeki dari orang lain (Amsal 22:9).

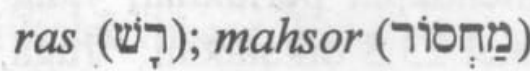

Kata ras ini hanya muncul di Amsal dengan frekuensi pemunculan sebanyak 15 kali. Kata ini ditujukan kepada (1) kaum yang cara hidupnya diwarnai dengan permintaan belas kasihan (18:23); (2) kaum yang tidak mempunyai teman $(14: 20 ; 19: 7)$; dan (3) kaum yang penderitaan kemiskinannya disebabkan oleh kemalasannya (10:4). Sedangkan kata mahsor muncul sebanyak 8 kali dengan mengindikasikan (1) kemiskinan 
sebagai akibat dari kemalasannya $(6: 11 ; 14: 23 ; 21: 5 ; 24: 34)$; dan (2) kemiskinan disebabkan oleh pemborosan (21:17).

\section{Kesimpulan}

Dari uraian di atas, kita dapat menyimpulkan bahwa ciri-ciri kelompok sosial kelas yang mempunyai kesejajaran dengan wong cilik tersebut di atas sebagai berikut: (1) kekurangan kebutuhan hidup; (2) secara sosial seorang yang tidak berdaya dan mudah menjadi obyek penindasan; (3) kaum yang ditindas, diperkosa hak-hak kewajaran kemanusiaannya; (4) tidak mendapat perlakuan hukum secara adil; (5) korban dari pembunuhan yang semena-mena oleh para penguasa; (6) penerima santunan dari orang lain; (7) kaum yang dilecehkan di lembaga-lembaga pengadilan; (8) kaum yang menderita karena eksploitasi dan penindasan dari kaum kuat; (9) kaum yang masih mampu membiayai kehidupannya sehari-hari tetapi karena ke-powerless-annya sehingga mudah ditindas oleh para penguasa; (10) kaum yang mempunyai padang gandum tetapi tidak kuat membayar beban pajak; (11) kaum yang mengadu tentang penderitaan kemiskinannya kepada Allah untuk mendapatkan keadilan; dan (12) kaum yang miskin karena disebabkan oleh kemalasan dan hidup yang boros.

Secara ringkas saya menyimpulkan bahwa Alkitab menggambarkan wong cilik bukanlah hanya kaum yang miskin tetapi juga kaum yang memiliki ladang gandum (Am 5:11) tetapi karena ke-powerless-annya maka mereka mudah ditindas, mendapat perlakuan yang tidak adil dan dieksploitasi hak-hak kewajarannya sebagai manusia.

\section{Keprihatinan Allah terhadap Wong Cilik}

Keprihatinan Allah terhadap wong cilik sungguh-sungguh mendapat tekanan dalam Perjanjian Lama, misalnya Allah menyatakan dirinya sebagai pelindung dan penolong wong cilik (Kel 20:22-23; Im 19:9-10; Ul 23:8; Za 7:9-10).

Beginilah firman Tuhan semesta alam: Laksanakanlah hukum yang benar dan tunjukkanlah kesetiaan dan kasih sayang kepada masing-masing! Janganlah menindas janda dan anak yatim, orang asing dan orang miskin, dan janganlah merancang kejahatan dalam hatimu terhadap masing-masing. (Zak 7:9-10).

Melalui nabi-nabinya Allah mengutuk penindasan dan perlakuan ketidakadilan terhadap wong cilik (Am 2:6-7; 5:10; Yer 5:8; 10:2; 22:3; Yeh 22:7). Mengapa Allah mempunyai perhatian yang besar terhadap wong cilik? Mengenai pertanyaan yang penting ini, O'Hagan mengajukan tiga pendapat yang secara ringkas dapat dikatakan sebagai berikut: (1) di 
dalam Alkitab sering orang kaya menjadi pelaku yang menindas wong cilik, dan mereka sangat materialistis, biasanya lebih mengutamakan harta mereka daripada Allah dan hukum-hukumnya. (2) Perhatian Allah terhadap wong cilik adalah merupakan sifatNya. Israel dipilih oleh Allah ketika bangsa Israel menjadi bangsa yang paling lemah. (3) Ada kecenderungan bahwa orang kaya memusatkan dirinya pada harta kekayaannya, berbeda dengan wong cilik mereka banyak berharap kepada Allah. $^{18}$

Jika Allah berprihatin terhadap wong cilik, itu bukan berarti bahwa Allah tidak mempunyai perhatian terhadap para priyayi, orang kaya, penguasa karena kekayaan itu sendiri berasal dari Allah (Kej 27:28, Ams 10:22). Akan tetapi Allah mengecam orang kaya dan penguasa yang menindas wong cilik, sebaliknya Allah memberkati orang kaya yang membagi makanan mereka terhadap wong cilik.

Beberapa bentuk ungkapan keprihatinan Allah terhadap wong cilik di Perjanjian Lama disebutkan berikut ini:

\section{Allah adalah Pembebas Kaum yang Tertindas}

Di dalam kitab Keluaran kita bisa melihat bentuk nyata dari keprihatinan Allah terhadap wong cilik yang tertindas. Bangsa Israel merupakan bangsa yang menderita dan hopeless, diperlakukan tidak adil oleh para penguasa masyarakat dan ditindas oleh para penguasa di Mesir. Israel betul-betul sangat miskin dan menjadi korban dari ketidakadilan.

Ketika bangsa Israel berteriak meminta tolong kepada Allah maka Allah bukan berpangku tangan tetapi dengan segera menyatakan keprihatinan-Nya: "Allah mendengar mereka mengerang, lalu Ia mengingat kepada perjanjian-Nya dengan Abraham, Ishak dan Yakub. Maka Allah melihat orang Israel itu, dan Allah memperhatikan mereka." '(Kel 2:24-25). Allah membebaskan wong cilik dari penindasan dan membawa ke suatu negeri yang baru.

Peristiwa pembebasan bangsa Isreal dari penudasan bangsa Mesir yang dipelopori oleh Allah sendiri ini, telah banyak ditafsirkan ke dalam berbagai dimensi. Gustavo Gutierrez dan Segundo - representatif dari aliran Teologi Pembebasan - melihat usaha-usaha pembebasan itu dari dimensi pembebasan tekanan politik yang diikuti dimensi agama. Gutierrez menyatakan:

The liberation of Israel is a Political Action. It is the breaking away from a situation of despoliation and muery and the beginning of the Construction of a just and fraternal socien It is the suppression of disorder and the creation of new order. The initial chapters of Exodus describe the oppression in which the Jewish people lived in Egypt, in that "land of 
slavery" (13:3; 20:2; Deut. 5:6); repression (1:10-11); alienated work (5:6-14); humiliations (1:13-14); enforced birth control policy (1:15-22).

Segundo juga mengatakan yang sama:

The Old Testament and the Exodus event in particular, show us two central elements completely fused into one: i.e., God the Liberator and the political process of liberation which leads the Israelites from bondage in Egypt to the promise land. ${ }^{20}$

Bagi mereka, "God of Exodus is the God of history and He is political liberator more than He is the God of nature." 21 Pandangan-pandangan ini ditolak oleh beberapa teolog dari kalangan Injili. Nunez $z^{22}$ menyatakan bahwa tujuan klimaks dari pembebasan adalah dimensi spiritual. Dia menyatakan sebagai berikut:

It is also evident that the Exodus had economic, social, and political consequences from Israel. But in spite of what might be said in the Theology of Liberation, the supreme purpose of that liberating deed was spiritual.

Fawcet juga mempunyai pendapat yang sama dengan Nunez, dia mengatakan bahwa pokok berita dari Alkitab adalah bukan sebuah janji dari penindasan yang sementara, tetapi ini merupakan sebuah berita tentang pembebasan dari akibat-akibat dosa. ${ }^{24}$ Pandangan ini terlalu memberi tekanan pada dimensi kerohanian, karena secara fakta Allah memperhatikan keduanya, yakni dimensi politik dan dimensi rohani. Kitab Keluaran 3:7-9 menyatakan:

Dan TUHAN berfirman: "Aku telah memperhatikan dengan sungguh kesengsaraan umatKu di tanah Mesir, dan Aku telah mendengar seruan mereka yang disebabkan oleh pengerah-pengerah mereka, ya, Aku mengetahui penderitaan mereka. Sebab itu Aku telah turun untuk melepaskan mereka dari tangan orang Mesir dan menuntun mereka keluar dari negeri itu ke suatu negeri yang baik dan luas, suatu negeri yang berlimpah-limpah susu dan madunya, tempat orang Kanaan, orang Het, orang Amori, orang Feris, orang Hewi, dan orang Yebus. Sekarang seruan orang Israel telah sampai kepada-Ku; juga telah Kulihat betapa kerasnya orang Mesir menindas mereka.

Allah bertindak membebaskan orang Israel juga didasarkan pada perjanjian Allah dengan nenek moyang Israel, Abraham, Isaak dan Yakub (Kel 6:5-7).

Jadi Allah memperhatikan keduanya seperti yang diungkapkan oleh Sider:

"The God of the Bible cares when people enslave and oppress others. At the Exodus he acted to end economic oppression and bring freedom to slaves. Now of course the liberation of oppresed slaves was not God's only purpose in the Exodus. God also acted because of His covenant with Abraham, Isaac, and Jacob. In addition, he wanted to create a special people to whom he could reveal himself. Both of these concerns were 
clearly central to God's activity at the Exodus. The liberation of the a poor, oppressed people, however, was also right at the heart of God's design.

Alasan yang lain adalah peristiwa pembebasan ini menjadi dasar bagi Allah dalam membuat hukum-hukum perlindungan bagi wong cilik dalam masyarakat Israel (Im 25:38; 42; 55; Ul 15:15).

Allah adalah Allah yang campur tangan dalam pembentukan sejarah manusia, Dia adalah yang aktif, pelindung bagi para wong cilik, dan pembebas bagi orang-orang yang tertindas.

2. Keprihatinan Allah terhadap wong cilik Direfleksikan melalui Hukumhukum-Nya

Penindasan kepada wong cilik (orang miskin, janda, anak yatim dan musafir) dilarang oleh Allah. Di dalam kitab Keluaran 22:21-24 dikatakan: "Janganlah kautindas atau kautekan seorang orang asing, ... Seorang janda atau anak yatim jangan kau tindas ..." dan beberapa hukuman disebutkan jika bangsa Israel tidak mengikuti perintah ini. Allah melindungi mereka karena mereka lemah dan mudah dieksploitasi. Bahkan di dalam Ul 10:18 perlidungan ini dihubungkan dengan diri Allah sebagai Hakim yang tertinggi yang tidak mau menerima suap tetapi mengusahakan keadilan kepada para janda, anak yatim, dan orang asing. ${ }^{26}$

\section{a. Hukum Sabat}

Di dalam kitab Keluaran 23:10-11 ditulis bahwa tahun Sabat diadakan untuk memberikan kesempatan kepada wong cilik supaya dapat makan: "Enam tahunlah lamanya engkau menabur di tanahmu dan mengumpulkan hasilnya, tetapi pada tahun ketujuh haruslah engkau membiarkannya dan meninggalkannya begitu saja, supaya orang miskin di antara bangsamu dapat makan ... Demikian juga kau lakukan dengan kebun anggurmu dan kebun zaitunmu. Enam harilah lamanya engkau melakukan pekerjaanmu, tetapi pada hari ketujuh haruslah engkau berhenti, supaya lembu dan keledaimu tidak bekerja dan supaya anak budakmu perempuan dan orang asing melepaskan lelah" (Kel 23:10-12).

Tujuan memberhentikan ladang untuk ditanami adalah supaya wong cilik yang miskin dapat makan. Di dalam tahun ini para budak juga menerima pembebasan (Ul 15:12-18) dan seluruh hutang-hutang dihapus (Ul 15:1-6). Ketaatan terhadap hukum ini akan mendapat berkat dari Allah, karena Allah berprihatin terhadap kesejahteraan orang miskin (U1 $15: 6)$. 


\section{b. Tahun Yobel}

Imamat 25 adalah salah satu teks yang paling radikal di antara teksteks Alkitab yang lain. Dalam pasal ini dikatakan bahwa setiap limapuluh tahun Allah memerintahkan untuk mengembalikan semua tanah yang sudah dibeli kepada para pemiliknya yang asli (Im 25:23-28). Prinsip dasar yang mendasari hukum ini adalah bahwa tanah adalah milik Allah sendiri yang dipercayakan pada bangsa Israel (Im 25:23). Tanah merupakan hal yang sangat esensial dalam menunjang kelangsungan ekonomi di Israel kuno karena dasar ekonomi pada waktu itu adalah pertanian. Tahun Yobel bertujuan untuk menjaga kemungkinankemungkinan keburukan ekonomi yang disebabkan oleh ketidakberuntungan wong cilik karena mereka terpaksa atau dipaksa untuk menjual tanahnya (25:26-27) atau tanah mereka hilang karena mereka menjadi miskin (25:25)

\section{c. Tithing dan Gleaning}

Hukum ini terdapat di dalam Imamat 19:9-10; Ulangan 14:18; 26:1215; Bilangan 18:21-32.

Pada waktu kamu menuai hasil tanahmu, janganlah kausabit ladangmu

habis-habis sampai ke tepinya, dan janganlah kaupungut apa yang ketinggalan dari penuaianmu. Juga sisa-sisa buah anggurmu janganlah kau petik untuk kedua kalinya dan buah yang berjatuhan di kebun anggurmu janganlah kaupungut, tetapi semuanya itu harus kautinggalkan bagi orang miskin dan bagi orang asing; ....." (Im. 19:9-10).

Butir-butir gandum yang jatuh harus ditinggalkan bagi orang miskin dan orang asing untuk diambilnya. Sebab kaum ini mempunyai pendapatan yang kecil dan harapannya kecil untuk hidup hanya dari pendapatannya yang didapat. Allah ingin para tuan tanah untuk bersyukur atas panen mereka dan sebagai ujud pernyataan syukurnya itu Allah memerintahkan mereka untuk berbagi hasil panen kepada orang-orang yang kurang beruntung (wong cilik).

\section{d. Penentangan Pembungaan Uang}

Di dalam kitab Pentateukh yang berisi pernyataan tentang hukum yang menentang pembungaan uang adalah Kel 22:24; Ul 23:20-21; dan Im 25:35-37. Tujuan dari pelarangan ini adalah untuk melindungi wong cilik yang miskin. Menurut Gamoran, peraturan ini dapat dimengerti dengan pemahaman sebagai berikut: (1) Karena peminjam adalah orang yang keadaan ekonominya tidak baik. (2) Meminjami uang adalah aksi yang benar untuk membantu meringankan kondisi kemiskinan seseorang. (3) 
Membungakan uang berarti dapat mengambil keuntungan dalam kemiskininan. (4) Hukum ini ditulis untuk melarang adanya tindakantindakan ketidakadilan. ${ }^{27}$

\section{Melalui Para Nabi-Nya Allah Mengutuk Penindasan terhadap Wong Cilik}

Di dalam kitab para nabi terlihat bahwa nabi-nabi Israel mempunyai perhatian tidak hanya terhadap isu moral dan agama tetapi juga isu-isu sosial. Ketidakadilan sosial bagi para nabi Israel merupakan alasan utama bagi datangnya hari penghakiman oleh Allah. Keprihatinan para nabi Israel terhadap ketidakadilan sosial direfleksikan melalui berita-berita yang disampaikan: Amos, di mana dia mengutuk eksploitasi dan penindasan orang-orang miskin dan orang-orang lemah $(4: 1 ; 5: 11 ; 8: 4,6)$. Yesaya mengutuk keadaan ketidakadilan $(1: 21,23 ; 5: 7 ; 10: 1-2 ; 58: 8)$, melupakan para janda dan anak yatim $(1: 23 ; 10: 2)$, dan penindasan bagi wong cilik $(3: 14-15 ; 10: 2)$. Yeremia mencela penindasan kepada orang miskin $(5: 28 ; 7: 6)$; dan pelecehan keadilan $(7: 5)$. Yehezkiel mencela penindasan terhadap orang miskin, janda, dan anak-anak yatim $(18: 12,16$; 22:29); dan Zakaria mencela pelupaan terhadap keadilan (7:9), penindasan pada para janda, anak yatim, dan orang asing (7:10).

Para nabi Israel memproklamasikan kepada bangsa Israel untuk

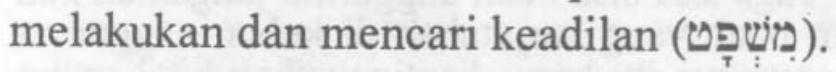

Berhentilah berbuat jahat, belajarlah berbuat baik; usahakanlah keadilan, kendalikanlah orang kejam; belalah hak anak-anak yatim, perjuangkanlah perkara janda-janda. (Yes 1:17).

Di dalam kitab syair dan hikmat, Allah melarang penindasan terhadap orang-orang miskin (Maz 132:15); Dia memperhatikan orang-orang miskin (Maz 72:13); setiap orang yang berbuat baik kepada orang-orang miskin.$(31: 9 ; 22: 22)$ dianggap sebagai orang yang berbahagia (14:21). Allah akan memberkati kepada orang yang membagi makanannya kepada orang-orang miskin (Ams 2:9), dan yang mempunyai belas kasihan terhadap kaum lemah (Ams 19:17). Akan tetapi Allah akan menutup telinga-Nya terhadap mereka yang menutup telinganya terhadap orang miskin (Ams 21:13).

Dari keseluruhan pembahasan di atas mengingatkan kepada kita semua bahwa Allah sangat memperhatikan nasib wong cilik. Bagaimana dengan kita? Kiranya pembahasan ini mengurangi skandalon-skandalon pemikiran kita yang cenderung rentan terhadap isu-isu di atas. Obstacle teologis yang telah diciptakan oleh warisan pemikiran para teolog terdahulu, secara tidak sadar telah memenjarakan kita ke dalam praduga- 
praduga yang kurang beralasan. Munculnya paham social gospel telah banyak membuat orang Kristen phobia untuk terlibat dalam penyelesaian masalah-masalah sosial yang ada. Seakan-akan melakukan pelayananpelayanan sosial tak ubahnya memutar dirinya mengikuti paham social gospel.

Artikel ini kiranya dapat membantu pemahaman kita, dalam tugas mengemban amanat Allah yang telah dipercayakan kepada orang-orang percaya. Sehingga kita semua lebih menjadi jelas akan tugas kita dalam berpartisipasi untuk mengatasi masalah-masalah sosial yang ada di sekitar kita, apalagi pada masa krisis ekonomi yang berkepanjangan ini.

\section{CATATAN AKHIR}

Koentjaraningrat menggunakan istilah Tiyang Alit untuk kata Wong cilik [Kebudayaan Jawa (Jakarta: Balai Pustaka, 1984)]. Sedangkan Franz MagnisSuseno, Etika Jawa Sebuah Analisa Falsafi tentang Kebijaksanaan Hidup Jawa (Jakarta: Gramedia, 1984) dan Sartono Kartodirdjo, A. Sudewo dan Suhardjo Hatmosuprobo, Perkembangan Peradaban Priyayi (Yogyakarta: Gajah Mada University Press, 1987) menggunakan istilah Wong cilik. Dalam tulisan ini dipakai istilah wong cilik bukan tiyang alit, sebab walaupun artinya sama istilah wong cilik lebih dikenal daripada tiyang alit. Bdk. Koentjaraningrat (peny.), "Kebudayaan Jawa," Manusia dan Kebudayaan di Indonesia (Jakarta: Djambatan, 1971).

2 Franz Magnis-Suseno, Beriman dalam Mayarakat: Butir-butir Teologi Kontekstual (Yogyakarta: Kanisius, 1993) 29.

${ }^{3}$ Lihat kasus-kasus penggusuran tanah di Lombok (Giliterawangan, Repek); Sumatra (Sirria-ria, Sei Ular, dan Sibolangit); Jawa Timur (Jenggawah); Jawa Barat (Majalengka, Cimacan, Kaca Piring) [Sri Harini Dwiyatmi, "Penguasaan Tanah Oleh Rakyat" Makalah Seminar pada Dies ke-40 UKSW, 1996].

+ "Melayani Orang Kecil: Pernyataan Sidang Pleno MASRI," 1984, dikutip oleh C. Putranta, SJ, "Gereja Kaum Miskin dalam Konsili Vatikan II dan Dokumen Federasi Konferensi Uskup-uskup Asia," Kemiskinan dan Pembebasan, diedit oleh J. B. Banawiratma, SJ (Yogyakarta: Kanisiua, 1987) 98.

${ }^{5}$ Lihat Helmer Ringgren, "גאל

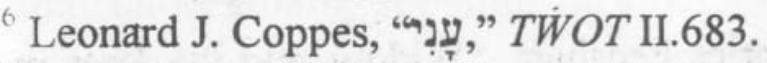

${ }^{7}$ Seperti yang diungkapkan oleh D.E. Holwerda: "These term are used to designate one who suffers not from a deserved, self-inflicted poverty but from a poverty caused by wrongful impoverishment or dispossession." ["poor" The International Standard Bible Encyclopedia (Geoffrey W. Bromiley, etal (peny.); Grand Rapids: Eerdmans, 1973) III.63].

${ }^{8}$ A. Rahlfs, 'Ani und 'ãnãw in den Psalmen (Göttingen, 1982), dikutip oleh HansJeoachim Kraus, Theology of the Psalms (Keith Crim [terj.]; Minnepolis: Augsburg, 1986) 150. 
9 Richard J. Coggins, "The Old Testament and the Poor," ExpTim 99 (October 1987-September 1988) 11.

${ }^{10}$ Sue Gillingham, "The Poor in the Psalms," ExpTim 100 (October 1988September 1989) 16.

"Ibid.

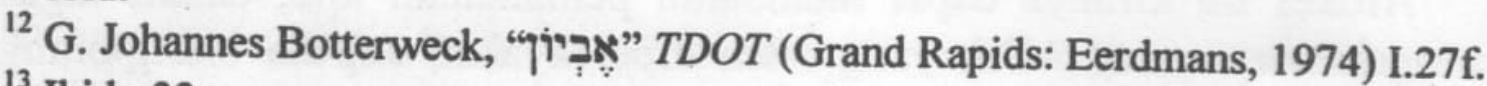

${ }^{13}$ Ibid., 33.

${ }^{14}$ Gillingham, "The Poor in the Psalms," 17.

${ }^{15}$ H. J. Fabry, “ר̦," TDOT (Grand Rapids: Eerdmans, 1978) III.208f.

${ }^{16}$ Ibid., 217.

${ }^{17}$ Zamani B. Kafang, A Semantic and Theological Investigation of the Concept of the "Poor" in the Psalms (Ann Arbor; Michigan: University Microfilms, 1993) 83-84.

${ }^{18}$ Angelo P. O'Hagan, "Poverty in the Bible," ABR 12 (1964) 2. Carolyn Osiek mendukung pendapat ini dengan mengatakan bahwa orang kaya secara umum kelihatan sombong dan cenderung menjadi penindas wong cilik, terutama dalam kitab nabi-nabi di mana mereka biasanya diidentikkan dengan para penguasa (Yes 3:14-15; Yer 22:13-17; Am 2:6-7; 5:11-12; 8:4-6; Mi 2:1-2; 3:1-3) ["Rich and Poor in the Sheperd of Hermes An Exegetical Social Investigation" $C B Q$ Monograph Series 15 (Washington: Catholic Biblical Association of America, 1983) 16].

19 Gustavo Gutierrez, A Theology of Liberation (Sister Caridad Inda and John Eagleson (terj. dan peny.); Maryknoll: Orbis, 1973) 155-156.

${ }^{20}$ Juan Luis Segundo, SJ, The Liberation of Theology (Maryknoll: Orbis, 1976) 110-111.

${ }^{21}$ Gutierrez, Theology of Liberation, 157.

${ }^{22}$ Angggota dari World Evangelical Fellowship dan Lausanne Continuation Committee.

${ }^{23}$ Emilion A. Nunez C., Liberating Theology (Paul E. Sywulka (terj.); Chicago: Moody, 1985) 35.

${ }^{24}$ Bruce G. Fawcett, "A Critical Analysis of Some Hermeneutical Principles Found in Latin American Theologies of Liberation," JETS 37:4 (1994) 575.

${ }^{25}$ Ronald J. Sider, Rich Christians in an of Hunger A Biblical Study (Downers Grove: Inter-Varsity, 1984) 55.

${ }^{26}$ Untuk diskusi lebih lanjut lihat F. Cahrles Fensham, "Widow, and the Poor in Ancient Near Eastern Legal and Wisdom Literature," JNES 21 (1962) 135; Donald E. Gowan, "Wealth and Poverty in the Old Testament The Case of the Widow, the Orphan, and the Sojourner," Interpretation XLI:4 (1987) 341-353.

${ }^{27}$ Hillel Gamoran, "The Biblical Law Against Loans on Interest," JNES 30 (1971) 130. 